\title{
A Preliminary Study on the Design Method for Large-Diameter Deep-Hole Presplit Blasting and Its Vibration-Isolation Effect
}

\author{
Shuangshuang Xiao $\mathbb{D}^{1,2}$ Hongsheng Wang $\mathbb{D}^{1,2}$ and Guowei Dong $\mathbb{D}^{1,2}$ \\ ${ }^{1}$ School of Energy Engineering, Xi'an University of Science and Technology, Xi'an, Shaanxi 710054, China \\ ${ }^{2}$ Shaanxi Provincial Key Laboratory of Ground Controlling, Xi'an, Shaanxi 710054, China \\ Correspondence should be addressed to Shuangshuang Xiao; kdxiaoshuang@163.com
}

Received 11 April 2019; Accepted 10 November 2019; Published 25 November 2019

Academic Editor: Radoslaw Zimroz

Copyright (c) 2019 Shuangshuang Xiao et al. This is an open access article distributed under the Creative Commons Attribution License, which permits unrestricted use, distribution, and reproduction in any medium, provided the original work is properly cited.

\begin{abstract}
Presplit blasting can reduce vibration and back impact induced by cast blasting, thus resulting in a smooth bench slope. To design reasonable presplit blasting parameters, this research investigated the formation of presplit faces based on the explosion mechanics and revealed the cracking mechanism of presplit blasting. According to the stress distribution in the vicinity of the blast holes under the action of explosive stress waves and blasting gas, we deduced theoretical formulae for parameters including charge mass in blast holes, hole spacing, and distance from presplit blast holes to cushion holes. On this basis, a method was proposed for the design of large-diameter deep-hole presplit blasting. Field testing was conducted by setting different spacing for presplit blast holes, to monitor the blasting-induced vibration. The results showed that appropriate hole spacing can reduce the particle vibration velocity and the attenuation index of blasting-induced vibration changed slightly while the attenuation coefficient decreased significantly; the formed presplit faces were smooth and had a high half-cast factor. Finally, the reasonable hole spacing for presplit blasting, distance from presplit blast hole to the cushion hole, and the charge mass in blast holes in the Heidaigou open-pit coal mine were determined, respectively.
\end{abstract}

\section{Introduction}

Presplit blasting is a controlled blasting technology setting dense blast holes along the excavation boundary which are detonated before blasting of primary blast holes, so as to form presplit cracks between the blast area and the reserved area. It reduces damage to the primary blast holes and reserved rock mass and forms smooth profiles after blasting $[1,2]$. Presplit blasting can decrease blasting-induced disturbance and damage, protect the integrity of the rock mass, and form a smooth excavation face. Owing to these advantages, the technology has been extensively used in numerous projects such as mines, railways, and hydraulic engineering works [3].

In an open-pit coal mine, the profile of the slope is generally controlled by the presplit blasting, so as to obtain a smooth slope and reduce ground motion induced by production blasting [4-6]. Presplit blasting is commonly used to reduce the back impact and produce smooth bench slopes after blasting in the mines applying cast blasting which causes severe damage to slopes due to the large quantities of charge used and violence of the blasting technology. The method can provide safe and uniformly burden-free faces for subsequent blasting [7-9].

In the 1960s, presplit blasting first found its large-scale use in electric power projects in Niagara. In terms of cracking mechanism, some scholars believed that the formation of presplit cracks is mainly as a result of the superposition of stress waves due to the simultaneous detonation of adjacent blast holes. Some scholars also suggested that the generation of high-pressure gas in the dynamite explosion plays a decisive role in the formation of the presplit cracks; however, more scholars believed that the presplit cracks are formed under the combined action of explosive stress waves and high-pressure gas [10]. To investigate the formation mechanism of the presplit cracks, 
Ling proposed a fracture mechanics model of presplit blasting to analyse the effects of stress waves and quasistatic pressure of blasting gas in a blasting-induced fracturing process [11]. Based on the Holmquist-Johnson-Cook model, $\mathrm{Hu}$ et al. built a dynamic damage model of presplit blasting and studied the evolution and formation process of the presplit cracks using numerical simulation [12]. Through numerical simulation, Cai et al. reproduced the shattering induced by dynamic impact, propagation, and superposition of stress waves and crack growth driven by blasting gas in a deep-hole presplit blasting process $[13,14]$. Wang et al. analysed the mechanism underpinning presplit blasting and applied it to control the caving of underground roadway roofs [15].

As to the design of presplit blasting parameters, some scholars discussed the use of theoretical calculations to determine relevant parameters of presplit blasting. For example, Chen et al. optimised the formulae proposed by Paine and proposed a calculation method for setting the distance of presplit blast holes [16]. To solve the difficulty in detonating all perimeter blast holes in perimeter blasting, Dai and Yang developed a method for calculating the parameters of controlled perimeter blasting on the condition that adjacent perimeter blast holes have delayed explosion times (they also verified its reliability) [17]. In accordance with the stress wave transmission theory, Cheng and Zhang deduced a formula for calculating the charge for horizontal presplitting [18]. Presplitting comes under the comprehensive influence of a set of factors including diameter and spacing of blast holes, behaviour of explosive, charge mass, charge structure, and physicomechanical properties of the rock mass [19-22]. As the theoretical formulae only consider some of these factors, they generally return significant calculation error. At present, parameters of presplit blasting are still dependent on empirical formula and improved through blasting trials, so there is a lack of a perfect design method [23].

As for the vibration-isolation action of presplit blasting, numerous scholars have studied the influences of the presplit face on the ground motion frequency and peak vibration velocity of particles between the blast area and the recording station and analysed the influences of width and depth of the presplit slot on the vibration-isolation effect [24-26]. Myer investigated the interaction between the explosive stress waves and presplit cracks using an interface model described using joint stiffness [27]. Taking peak vibration velocity of particles as the main index, $\mathrm{Hu}$ et al. discussed the propagation characteristics of explosive stress waves under filling conditions and their attenuation while passing through interfaces between presplit cracks and different media by numerical simulation [28]. Lu et al. revealed the vibrationisolation mechanism of the presplit cracks by analysing the interaction between explosive stress waves and presplit cracks and studied the closure and vibration-isolation effect of presplit cracks under the effect of explosive stress waves [29]. Hu et al. investigated the damage process induced by smooth blasting and presplit blasting using numerical simulation and compared the damage caused using the two blasting techniques in high rock slopes [30]. They believed that the damage to the rock slope is mainly induced by presplit blasting when that blasting technique is used to control the gradient of the slope.

The above analysis shows that although presplit blasting has long been studied, a recognised cracking mechanism underpinning presplit blasting remains unclear, as well as a systemic and feasible design method for presplit blasting due to characteristics such as high temperature, pressure, speed of blasting, and anisotropy of the rock mass. The vibrationisolation effects of presplit blasting are generally studied using theoretical calculation and numerical simulation, while there are few field studies thereof. Furthermore, smalldiameter, decoupling charges are commonly adopted in presplit blasting in practical engineering applications: however, owing to the size of most open-pit coal mines, large linear dimensions of production equipment, and massive production capacity required, open-pit coal mines, especially those applying cast blasting, call for the application of large-diameter deep-hole presplit blasting. The formulae for designing parameters of presplit blasting under conditions of charging in small-diameter holes are not absolutely applicable in that context, so relevant studies are rare.

This research demonstrated the presplit blasting mechanism at first. A method for determining the parameters of deep-hole presplit blasting was then proposed based on the theory of blasting. Moreover, field test was carried out to optimise and ascertain the parameters and analyse the vibration-isolation effect of presplit blasting.

\section{Analysis of Cracking Mechanism of Presplit Blasting}

In accordance with the theory of rock blasting, a crushed zone, a cracked zone, and an elastically vibrated zone are formed in a rock mass when the explosive is detonated in an infinite rock mass (Figure 1).

Among these zones, the crushed zone is formed due to compression failure of rocks under actions of pressure of blast waves and high temperature, and pressure of blasting gas. Under conditions of columnar coupling charge, the radius of the crushed zone is [17] given by

$$
R_{\mathrm{c}}=\left[\frac{\sqrt{2} \rho_{0} D^{2} \rho C_{\mathrm{p}} B}{4 \sigma_{\mathrm{cd}}\left(\rho C_{\mathrm{p}}+\rho_{0} D\right)}\right]^{1 / \alpha} r_{\mathrm{b}},
$$

where $\rho_{0}$ and $\rho$ represent densities $\left(\mathrm{kg} / \mathrm{m}^{3}\right)$ of the explosive and the rocks, respectively; $C_{\mathrm{p}}$ denotes the sound velocity $(\mathrm{m} / \mathrm{s})$ in rocks; $D$ denotes the explosive detonation velocity $(\mathrm{m} / \mathrm{s}) ; \sigma_{c d}$ refers to the dynamic uniaxial compressive strength $(\mathrm{Pa})$; and $r_{\mathrm{b}}$ is the radius $(\mathrm{m})$ of the blast holes. $\alpha=\left(2-\mu_{\mathrm{d}}\right) /\left(1-\mu_{\mathrm{d}}\right)$ and $B=\sqrt{2\left(b^{2}+b+1\right)-2 \mu_{\mathrm{d}}\left(1-\mu_{\mathrm{d}}\right)(1-b)^{2}}$, where $b$ is the lateral stress coefficient, $b=\left(\mu_{\mathrm{d}}\right) /\left(1-\mu_{\mathrm{d}}\right)$, and $\mu_{\mathrm{d}}$ refers to the dynamic Poisson's ratio of rocks.

The cracked zone is formed by the tensile stress of the stress waves and the air wedging effect of blasting gas. When using columnar coupling charges, the radius of the cracked zone is given by 


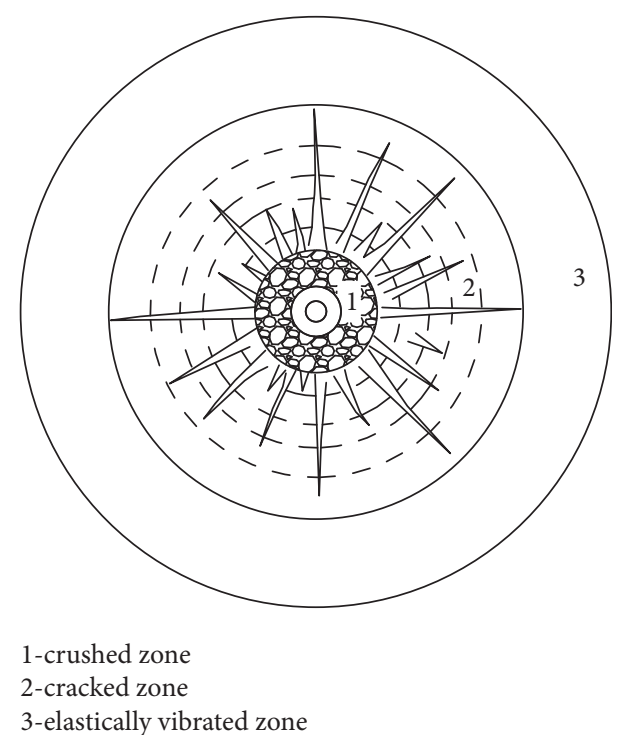

FIGURE 1: Divisions induced by blasting in an infinite rock mass.

$$
R_{\mathrm{p}}=\left(\frac{\sigma_{\mathrm{R}} B}{\sqrt{2} \sigma_{\mathrm{td}}}\right)^{1 / \beta} R_{\mathrm{c}}
$$

where $\sigma_{\mathrm{td}}$ refers to the dynamic uniaxial tensile strength $(\mathrm{Pa})$ of rocks; $\sigma_{\mathrm{R}}=\sigma_{r \mid r=R_{c}}=\sqrt{2} \sigma_{\mathrm{cd}} / B$; and $\beta=\left(2-3 \mu_{\mathrm{d}}\right) /\left(1-\mu_{\mathrm{d}}\right)$.

In blasting engineering, it can be stated that $\mu_{\mathrm{d}}=0.8 \mu$ where $\mu$ denotes the static Poisson's ratio. For ordinary rocks in blasting, it is approximately that $\sigma_{\mathrm{cd}}=\varepsilon^{1 / 3} \sigma_{\mathrm{c}}$, in which $\sigma_{\mathrm{c}}$ is the static uniaxial compressive strength of rocks and $\varepsilon$ refers to the loading strain rate and values $\varepsilon=10^{2}-10^{4} \mathrm{~s}^{-1}$ in the crushed zone. The dynamic uniaxial tensile strength of rocks varies with loading strain rate, so $\sigma_{\mathrm{td}}=\sigma_{\mathrm{t}}$, where $\sigma_{\mathrm{t}}$ denotes the static uniaxial tensile strength of the rock.

The region outside the cracked zone is an elastically vibrated zone, where the rocks undergo only elastic vibration, with no damage thereto.

The purpose of presplit blasting is not to crush rocks, but to separate the rock mass in the blast area and the reserved area and form presplit cracks. Therefore, the blasting technology generally adopts decoupling charges or lowdensity explosive, so that the pressure on the hole wall produced by the explosion is smaller than the dynamic uniaxial compressive strength of rocks, and rocks around the hole wall remain undamaged under pressure. That is, no crushed zone is formed. The presplit cracks are formed as described below.

When adjacent presplit blast holes are detonated at the same time, rock at the hole wall is exposed to a violent impact pressure and stress waves propagate from the hole, thus producing compressive stress in the axial direction and tensile stress in a tangential direction. Long axial initial cracks appear on the blast hole walls along the lines connecting hole centres due to the stress concentration and superposition of stress waves (Figure 2(a)) [31]. Afterwards, the effect of the quasistatic stress of the blasting gas causes the axial cracks to interconnect and propagate. As the longest axial crack needs the least energy to propagate, the direction of the line connecting hole centres is the preferred direction for crack propagation. In comparison, cracks in other directions develop less, thus ensuring the connection of cracks along the direction of the line of hole centres. Finally, connected cracks of a certain width are formed (Figure 2(b)) [32, 33].

\section{Engineering Geology of the Mine}

Coal seams in the Heidaigou (HDG) open-pit coal mine (Junggar Coalfield, Inner Mongolia, China) were buried $105 \mathrm{~m}$ underground on average, in which the loess and the rocks are, respectively, 49 and $56 \mathrm{~m}$ thick. The primary mineable coal seam is the No. 6 seam with an average thickness of $28.8 \mathrm{~m}$. The loess was continuously stripped using a bucket wheel excavator, a belt conveyor, and a dump machine; the upper rocks were stripped based on discontinuous mining technology with a single-bucket excavator and a truck; rocks to $42 \mathrm{~m}$ thick above the No. 6 coal seam were exfoliated by combining cast blasting and dragline stripping technology; the coal seam was mined adopting a semicontinuous method with a single-bucket excavator, a truck, a semifixed crushing station, and a belt conveyor (Figure 3).

Strata in the benches formed using the cast blasting are mainly distributed in layers with gentle slopes. The strata include coarse-grained sandstone, fine-grained sandstone, and mudstone (Table 1).

At present, the HDG open-pit coal mine produces more than $3 \times 10^{8} \mathrm{Mg}$ raw coal per annum. The benches formed by cast blasting are $42 \mathrm{~m}$ high (on average). The area of cast blasting is $85 \mathrm{~m}$ wide and $660 \mathrm{~m}$ or $440 \mathrm{~m}$ long (Figure 4). During cast blasting, holes are detonated one by one (by section) and salient parameters related to the cast blasting are given in Table 2 [34]. The line connection mode and detonation sequence are shown in Figure 5.

At present, there are no buildings near the blasting area, and the production equipment is generally outside the blasting area of $600 \mathrm{~m}$, which is less affected by blasting vibration. To decrease the back impact of cast blasting and form smooth bench slopes, presplit blasting was used together with cast blasting in the HDG open-pit coal mine.

\section{Parameter Design for Presplit Blasting}

The key to presplit blasting is to produce connected presplit cracks; however, presplit blast holes are detonated under conditions in which there are no free faces in the frontage. If the blasting parameters are unreasonably designed, closed microcracks are generally produced in hard rock mass; therefore, microcracks are generally developed along the joints and fractures adjacent to presplit blast holes in soft and crushed rock masses, so that the structural plane of a rock mass is seriously damaged, allowing the appearance of damage induced by back impact after the blasting of adjacent blast holes. Therefore, it is necessary to design the presplit blasting parameters according to the mechanism underpinning presplit blasting while considering the influences 


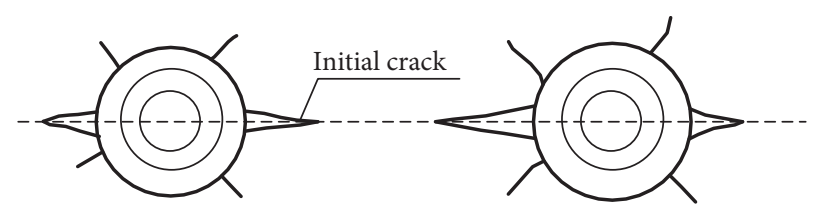

(a)

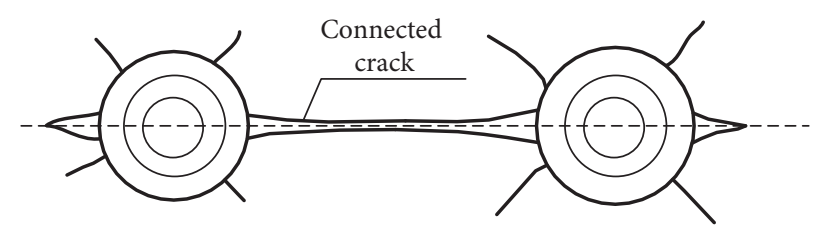

(b)

FIgURE 2: Formation of a presplit face.

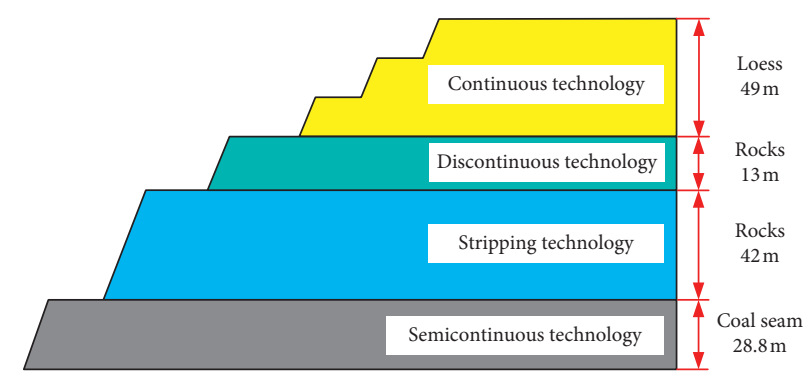

FIgURE 3: Application of various production technologies.

TABLE 1: Stratigraphic column through cast-blasting benches.

\begin{tabular}{|c|c|c|c|c|c|c|}
\hline Stratigraphic order & Lithology & Lithological column & Depth (m) & Thickness (m) & $\begin{array}{l}\text { Unit weight } \\
\left(\mathrm{Mg} / \mathrm{m}^{3}\right)\end{array}$ & $\begin{array}{l}\text { Uniaxial compressive strength } \\
(\mathrm{MPa})\end{array}$ \\
\hline 10 & Siltstone & & 91.6 & 5.4 & 2.4 & 43.4 \\
\hline 11 & Packsand & & 93.6 & 2.0 & 2.5 & 53.4 \\
\hline 12 & Mudstone & -- & 94.6 & 1.0 & 2.6 & 44.2 \\
\hline 13 & Siltstone & & 97.4 & 2.8 & 2.4 & 43.4 \\
\hline 14 & Packsand & & 101.8 & 4.4 & 2.5 & 53.4 \\
\hline 15 & Coarse sandstone & & 114.6 & 12.8 & 2.2 & 28.8 \\
\hline 16 & No. 5 coal seam & & 116.2 & 1.6 & 1.4 & 14.7 \\
\hline 17 & Sandy mudstone & \begin{tabular}{|l|}
$-\cdot-\cdot$ \\
$-\cdot-\cdot \cdot$ \\
$\cdot-\cdot-\cdot$ \\
\end{tabular} & 120.7 & 4.5 & 2.5 & 47.7 \\
\hline 18 & Coarse sandstone & & 128.2 & 7.5 & 2.2 & 28.8 \\
\hline
\end{tabular}

of factors such as behaviour of explosive and the physicomechanical properties of the rock mass $[35,36]$.

As the explosive cartridge is heavy (for large-diameter deep holes), this leads to difficulties in transport and filling and affects the construction schedule, and an air-deck charge is generally used, instead of an axial decoupling charge. Moreover, the application of the low-density charge can reduce the detonation pressure: when the charge mass is 


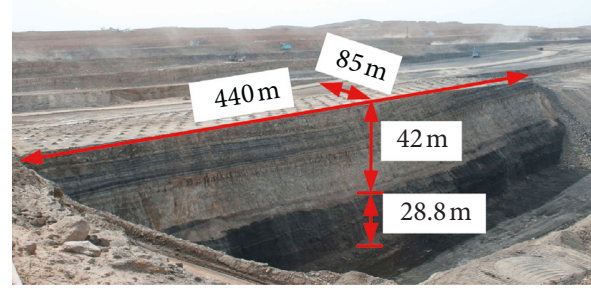

(a)

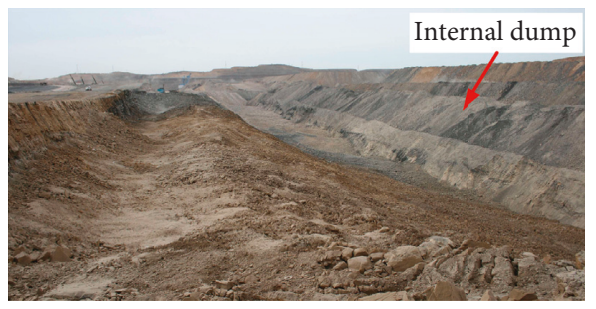

(b)

Figure 4: Conditions before, and after, cast blasting. (a) High benches of cast blasting and (b) muck pile of cast blasting.

TABLE 2: Cast-blasting parameters.

\begin{tabular}{lccc}
\hline Parameter & Symbol & Unit & \\
\hline Hole diameter & $d$ & $\mathrm{~mm}$ & Value \\
Minimum burden & $W$ & $\mathrm{~m}$ & 310 \\
Spacing & $a$ & $\mathrm{~m}$ & $6.0 \sim 6.5$ \\
Array pitch & $b$ & $\mathrm{~m}$ & $9 \sim 12$ \\
Hole angle & $\beta$ & $\mathrm{kg} / \mathrm{m}^{3}$ & $7 \sim 9$ \\
Powder factor & $q$ & $\mathrm{~m}$ & 65 \\
Stemming length & $l$ & $\mathrm{~ms}$ & $0.7 \sim 0.8$ \\
Delay between holes & $t_{k}$ & $\mathrm{~ms}$ & $6 \sim 8$ \\
Delay between rows & $t_{\mathrm{p}}$ & $\mathrm{ms}$ & $9 \sim 20$ \\
Delay in hole & $t_{\mathrm{n}}$ & $100 \sim 200$ \\
\end{tabular}

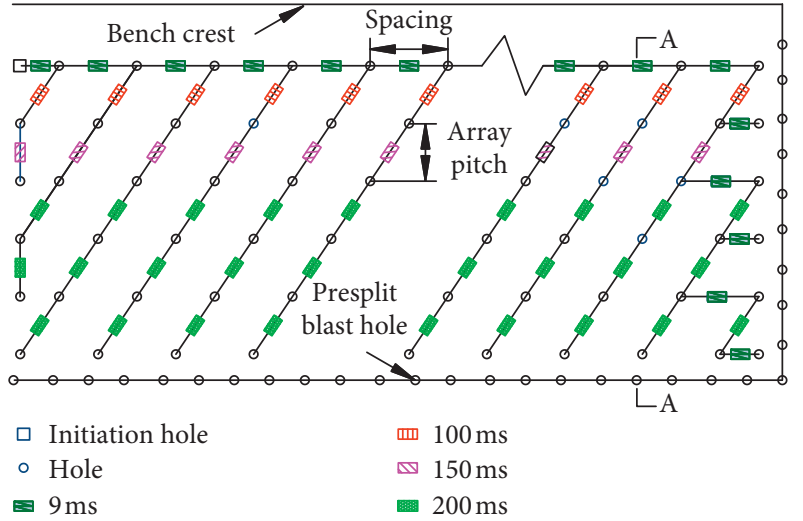

(a)

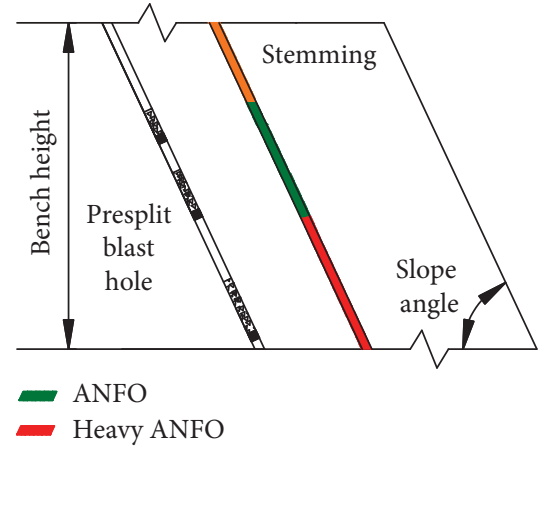

(b)

FIGURE 5: Sketch map showing cast-blasting parameters. (a) Hole pattern parameters and (b) indicative loading design.

fixed, it can increase the charge length and therefore improve the distribution of stress produced by the explosive in the axial direction of the blast holes.

Main parameters in large-diameter deep-hole presplit blasting include blast hole diameter, dip angle of blast holes, charge mass in the hole, and hole spacing. Among them, hole spacing and charge mass are the most important parameters in presplit blasting. If the spacing between blast holes is large, it is difficult to form smooth presplit faces; on the contrary, the number of presplit blast holes needs to be increased, which results in a high drilling cost. A large charge mass in the blast hole is likely to damage the walls of the presplit blast holes, while a low charge mass is unable to form a presplit face.
4.1. Diameter of Blast Holes. The diameter of blast holes directly influences the efficiency and production cost of construction and needs to be determined by considering geological conditions, type of drilling machines used in the field, and the depth of presplit blast holes.

The holes drilled using a large-diameter drilling machine are subject to smaller deviations and have a greater depth. Increasing the hole diameter can enlarge hole spacings and therefore reduce the workload associated with drilling. Moreover, cast blasting in the HDG open-pit coal mine relied on a DM-H2 drilling machine to drill holes (diameter: $310 \mathrm{~mm}$ ). Therefore, the diameter of presplit blast holes was also set to $310 \mathrm{~mm}$ in order to simplify construction. 
4.2. Dip Angle of Blast Holes. The dip angle of presplit blast holes is generally the same as that of the production holes. The dip angle of inclined blast holes is generally between $65^{\circ}$ and $75^{\circ}$ according to engineering experience: any dip angle below $65^{\circ}$ will lead to difficulties in the drilling and charging stages.

As the high benches in the HDG open-pit coal mine frequently collapsed when blast holes were drilled with a dip angle of $70^{\circ}$, the dip angle of blast holes was set to $65^{\circ}$ to ensure the stability of each step.

4.3. Charge Mass in Blast Holes. When an air-deck charge is used, the impact pressure on the walls of blast holes is as follows:

$$
p_{2}=\frac{n l_{c} \rho_{0} D^{2}}{8 l_{\mathrm{b}}}
$$

where $n, l_{\mathrm{c}}, l_{\mathrm{b}}$, and $H$ represent the increase factor on the pressure (generally 10$)$, the charge length $(\mathrm{m})$, length $(\mathrm{m})$ of blast holes, $l_{\mathrm{b}}=H / \sin \beta$, and height $(\mathrm{m})$ of benches, respectively.

To avoid rock forming the walls around each blast hole from being crushed, and to form interconnected cracks, $p_{2} \leq \sigma_{\text {cd }}$, and it can be obtained from formula (3) that

$$
l_{\mathrm{c}} \leq \frac{8 l_{\mathrm{b}} \sigma_{\mathrm{cd}}}{n \rho_{0} D^{2}}
$$

The charge mass in each blast hole is given by

$$
Q=\frac{\pi d^{2} l_{c} \rho_{0}}{4}
$$

where $Q$ represents the charge mass $(\mathrm{kg})$ in each blast hole. The empirical formula commonly used for ascertaining the charge mass in a blast hole is as follows:

$$
\mathrm{Q}=l_{\mathrm{b}} S q_{\mathrm{a}}
$$

where $S$ denotes the spacing between blast holes $(\mathrm{m})$ and $q_{\mathrm{a}}$ represents the quantity of explosive consumed per unit area of presplit face, commonly between 0.9 and $1.3 \mathrm{~kg} / \mathrm{m}^{2}$.

A low-density ammonium nitrate fuel oil was selected for presplit blasting in the HDG open-pit coal mine. The density and detonation velocity of the explosive are $\rho_{0}=600 \mathrm{~kg} / \mathrm{m}^{3}$ and $D=1,800 \mathrm{~m} / \mathrm{s}$, respectively. The static uniaxial compressive strength of rocks is $\sigma_{\mathrm{c}}=37.3 \mathrm{MPa}$ and $\mathcal{E}=10^{2} \mathrm{~s}^{-1}$. It can be found, using formula (4), that $l_{\mathrm{c}} \leq 3.3 \mathrm{~m}$. By substituting $l_{\mathrm{c}} \leq 3.3 \mathrm{~m}$ in formula (5), it can be found that $Q=149.5 \mathrm{~kg}$.

4.4. Spacing of Blast Holes. When the impact pressure on the walls of blast holes is $p_{2}$, the maximum tensile stress produced at distance $R$ from the centre of the blast hole is given by

$$
\sigma_{\theta}=\left(\frac{r_{\mathrm{b}}}{R}\right)^{\alpha} b p_{2}
$$

According to $\sigma_{\theta}=\sigma_{\mathrm{td}}$, the length of the initial cracks in each blast hole can be calculated as follows:

$$
R_{k}=\left(\frac{b p_{2}}{\sigma_{\mathrm{td}}}\right)^{1 / \alpha} r_{\mathrm{b}} .
$$

To make the initial cracks propagate and develop to connected cracks, the following condition should be met:

$$
\left(S-2 R_{k}\right) \sigma_{\mathrm{td}}=2 r_{\mathrm{b}} p_{1}
$$

where $S$ represents the spacing $(\mathrm{m})$ of blast holes and $p_{1}$ is the static pressure $(\mathrm{Pa})$ when the blast hole is filled with blasting gas. In addition, $p_{1}$ can be calculated using the following formula:

$$
p_{1}=\left(\frac{p_{\mathrm{c}}}{p_{k}}\right)^{\gamma / k}\left(\frac{V_{\mathrm{c}}}{V_{\mathrm{b}}}\right)^{\gamma} p_{k},
$$

where $p_{\mathrm{c}}$ represents detonation pressure $\left(p_{\mathrm{c}}=\rho_{0} D^{2} / 4\right)$ and $p_{k}$ refers to the critical pressure during the expansion of blasting gas (generally $200 \mathrm{MPa}$ ). Meanwhile, $V_{\mathrm{c}}, V_{\mathrm{b}}, \gamma$, and $k$ denote charge volume $\left(\mathrm{m}^{3}\right)$, volume $\left(\mathrm{m}^{3}\right)$ of blast holes, adiabatic expansion index of air, and isentropic exponent of explosive, respectively. In the research, $\gamma$ and $k$ are 1.4 and 3, respectively.

The following theoretical formula of distance of blast holes can be obtained from formula (9):

$$
S=2 R_{k}+\frac{2 r_{\mathrm{b}} p_{1}}{\sigma_{\mathrm{td}}}
$$

The empirical formula commonly used for determining the distance of blast holes is [37] as follows:

$$
S=(8-13) d \text {. }
$$

The dynamic uniaxial tensile strength and dynamic Poisson's ratio of rocks in the benches formed due to cast blasting are $\sigma_{\mathrm{td}}=2.6 \mathrm{MPa}$ and $\mu_{\mathrm{d}}=0.20$. Then, it is found that $S=4.0 \mathrm{~m}$ using formulae (3), (8), (10), and (11).

It is found that $S \approx 3.4 \mathrm{~m}$ when $S=11 \mathrm{~d}$ according to the empirical formula. Suppose that $q_{\mathrm{a}}=0.95 \mathrm{~kg} / \mathrm{m}^{2}, Q=$ $150.1 \mathrm{~kg}$ can be obtained based on formula (6).

4.5. Distance to the Cushion Hole. Too small a distance between the presplit blast hole and a cushion hole is likely to damage the presplit face, while if the distance is too large, the rocks in front of the presplit blast holes cannot be crushed sufficiently to produce a large amount of blocks. The distance between the presplit blast hole and the cushion hole can be determined using the following formula:

$$
W=2 r_{\mathrm{b}}\left\{\frac{\rho_{0} D^{2} \rho C_{\mathrm{p}} b}{2 \sigma_{\mathrm{td}}\left[\rho C_{\mathrm{p}}+\rho_{0} D\right]}\right\}^{1 / \beta} .
$$

The empirical formula commonly used to determine $W$ is given by

$$
W=\frac{S}{m}
$$

where $m=0.7$ to 1.0 .

It can be found using formula (13) that $W=3.9 \mathrm{~m}$. Suppose that $m=0.85$, then it is found from formula (14) 
TABle 3: Presplit blasting parameters.

\begin{tabular}{lccc}
\hline Parameter & Unit & Value \\
\hline$d$ & $\mathrm{~mm}$ & 310 \\
$\beta$ & $\circ$ & 65 & \\
$Q$ & $\mathrm{~kg}$ & Theoretical value & 149.5 \\
& & Empirical value & 150.1 \\
$S$ & $\mathrm{~m}$ & Theoretical value & 4.0 \\
& & Empirical value & 3.4 \\
$W$ & $\mathrm{~m}$ & Theoretical value & 3.9 \\
& & Empirical value & 4.0 \\
\hline
\end{tabular}

that $W=4.0 \mathrm{~m}$. The salient parameters pertaining to the presplit blasting used here can be determined in Table 3.

4.6. Charge Structure. The designed charge structure needs to enable the explosive to be distributed as uniformly as possible in blast holes. To avoid damage to the presplit face around these presplit blast holes, filling a certain section of the hole below the hole mouth with explosive should be avoided. Due to the large clamping effect at the bottom of the hole, the charge mass is increased at the bottom.

An air-spacer divided charge structure was used in these presplit blast holes. Each hole was filled with explosive in three sections: the first section was at the bottom of the hole and $L_{1}=1 \mathrm{~m}$ higher than the roof of the coal seam, where $Q_{1}=0.5 Q$ of explosive was loaded; the second section was $L_{2}=25 \mathrm{~m}$ to the hole mouth and $Q_{2}=0.3 Q$ of explosive was filled therein; the third section was $L_{3}=15 \mathrm{~m}$ to the hole mouth, where the charge mass was $Q_{3}=0.2 Q$.

As it is able to simplify the procedure, reduce associated workloads, and meet the requirements for production capacity in open-pit coal mines, presplit blast holes were not sealed in the HDG open-pit coal mine.

4.7. Detonating Network. To reduce the vibration induced by presplit blasting, grouped packet delay detonation was used. Every 20 presplit blast holes were classified within a single group. Those detonators in holes in the same group were detonated quasisimultaneously, with a delay time of $9 \mathrm{~ms}$ between detonations. A detonating cord was adopted to fire the Nonel detonators in the holes which then detonated the igniting primer ( $600 \mathrm{~g}$ mass) so as to ignite the explosive. The explosive in the presplit blast holes was detonated at between 500 and $600 \mathrm{~ms}$ before the primary blast hole detonations.

The charge structure and detonating network of the presplit blasting are illustrated in Figure 6 .

\section{Field Application}

According to the theoretical formula for calculating parameters of presplit blasting, let $\sigma_{\mathrm{t}}=2.6 \mathrm{MPa}$, then the relationships of $Q, S$, and $W$ with $\sigma_{\mathrm{c}}$ can be obtained (Figure 7(a)); let $\sigma_{\mathrm{c}}=37.3 \mathrm{MPa}$, the relationships of $\mathrm{Q}, S$, and $W$ with $\sigma_{\mathrm{t}}$ can also be derived (Figure $7(\mathrm{~b})$ ). Figure 7 indicates that as the static uniaxial compressive strength $\sigma_{\mathrm{c}}$ of rocks increases, the charge mass $Q$ and distance $S$ of blast holes both grow at a quasiconstant rate with a fixed distance $W$ to the cushion holes. Therein, $Q$ increases at a

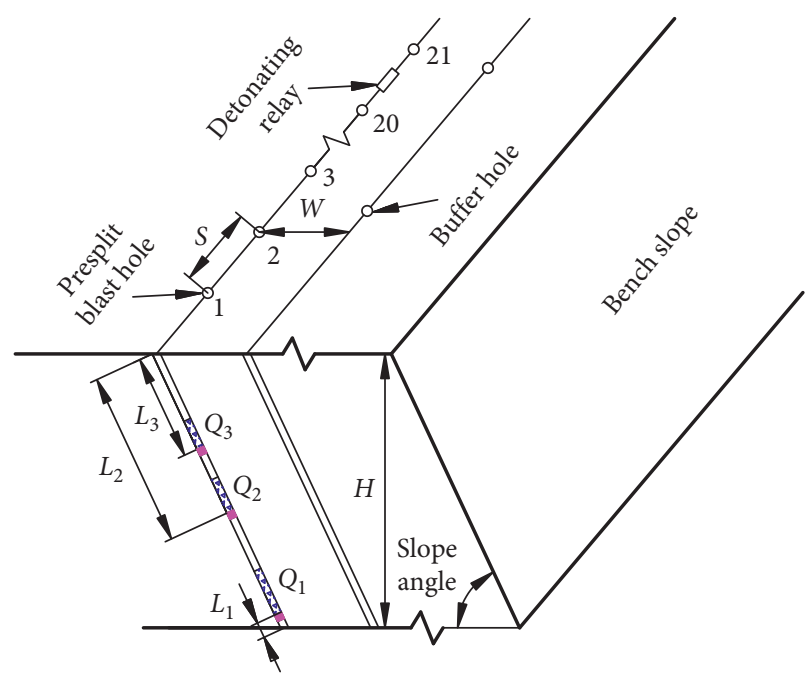

FIGURE 6: Sketch map of the charge structure and detonating network for presplit blasting.

faster rate. With increasing static uniaxial tensile strength of rocks, the spacing between blast holes and the distance to cushion holes both decrease when using a fixed charge mass in the blast holes, while the rate of decrease gradually slows.

According to the calculation results, the design relied on $Q=150 \mathrm{~kg}, W=4.0 \mathrm{~m}$, and $S=3.4 \mathrm{~m}$ or $S=4.0 \mathrm{~m}$, and other parameters are the same when conducting presplit blasting tests in situ. Measuring points were set in the rear and to the side of the blast area (Figure 8). To collect vibration waveform data, a TC- 4850 blasting vibration meter was used to monitor the vibration velocities of blasting particles at each measurement point (Figure 9). The vibration-isolation effects of presplit blasting at $S=3.4 \mathrm{~m}$ and $S=4.0 \mathrm{~m}$ were compared based on the monitored data.

The monitored typical waveforms are shown in Figure 10. At the point of measurement, the maximum resultant velocity is $10.3 \mathrm{~mm} / \mathrm{s}$, found at $1.537 \mathrm{~s}$, and the vibration induced by blasting lasts for about $3 \mathrm{~s}$. The peak vibration velocity in the axial direction (Long) is generally the largest compared with those in vertical (Vert) and transverse (Tran) directions. The vector resultant velocity is approximately equal to the axial peak vibration velocity, both appearing quasisimultaneously. The maximum vibration velocity induced by blasting is generally found between 1.2 and $1.8 \mathrm{~s}$. The vibration velocity is initially low, indicating that the blast-induced vibration components contain small-energy $\mathrm{P}$-waves, high-energy S-waves, and surface waves with a low propagation velocity.

The monitoring data are reported in Table 4 . When other parameters are kept unchanged, the vibration velocity of particles at $S=3.4 \mathrm{~m}$ is low and the vibration-isolation rate is $20.7 \%$ (on average).

Suppose that $Q_{\mathrm{d}}$ and $R_{\mathrm{b}}$ represent the charge mass per unit delay interval and the distance from the monitoring point to the centre of the blasting source. Let the equivalent distance be $X=R_{\mathrm{b}} / \sqrt[3]{Q_{\mathrm{d}}}$, the relationship between the vibration velocity $v$ of particles and the equivalent distance $X$ is obtained (Figure 11). 

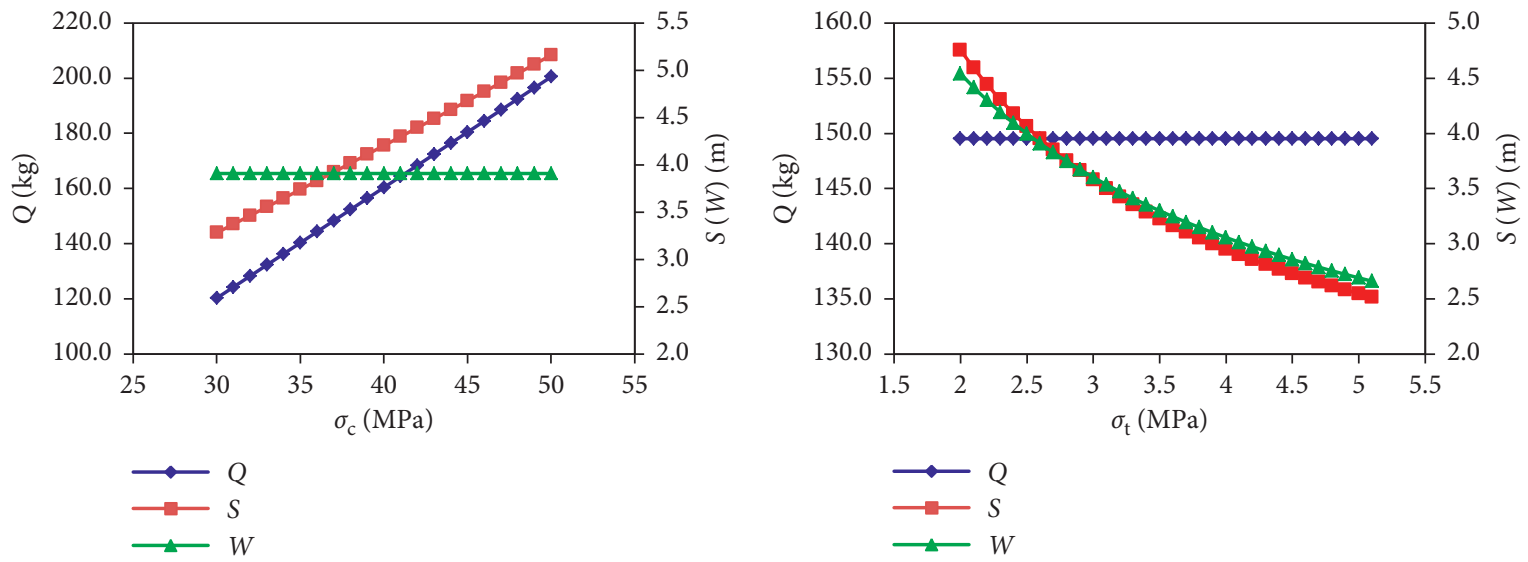

(a)

(b)

Figure 7: Relationships of $Q, S$, and $W$ with $\sigma_{\mathrm{c}}(\mathrm{a})$ and with $\sigma_{\mathrm{t}}(\mathrm{b})$.

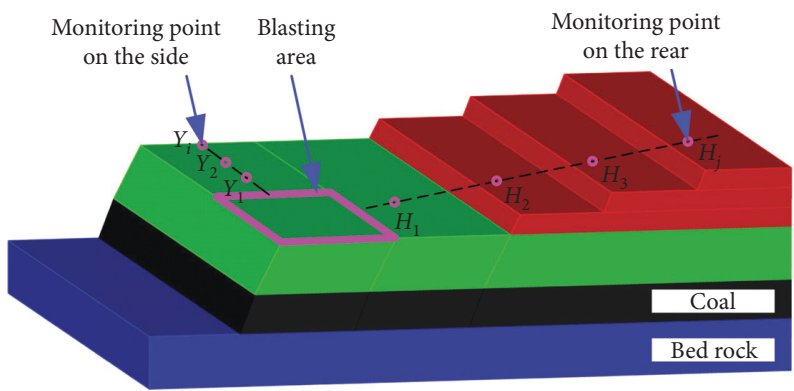

Figure 8: Sketch map of layout of monitoring points.

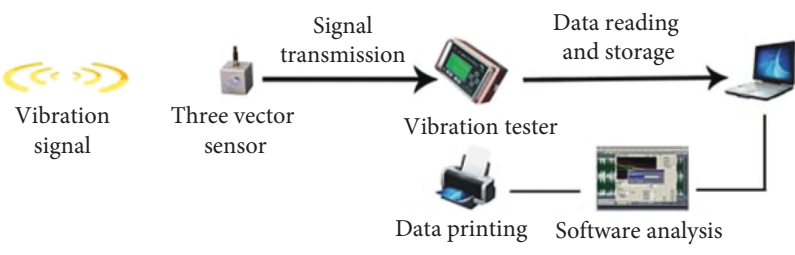

FIGURE 9: Working diagram of the apparatus.

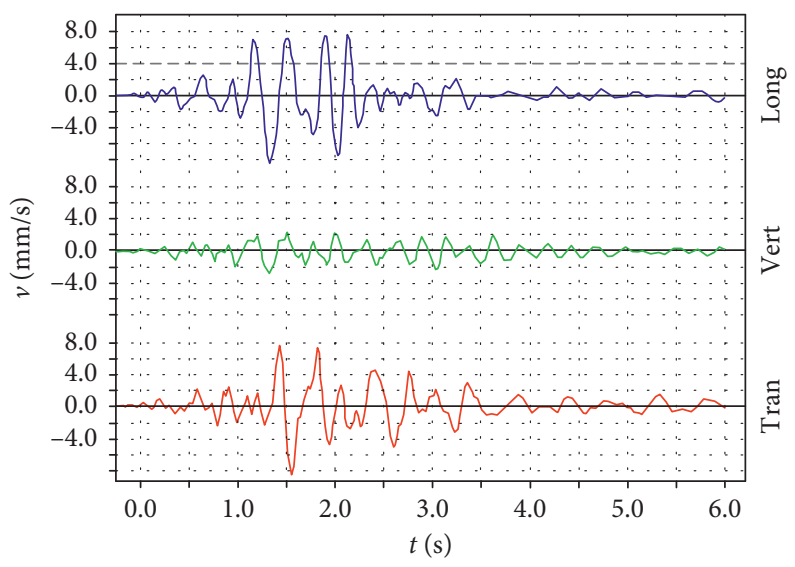

FIgURE 10: Typical waveforms associated with blasting-induced vibration. 
TABLE 4: Monitoring data and vibration-isolation effect during presplit blasting.

\begin{tabular}{lcccccc}
\hline \multirow{2}{*}{ Monitoring point } & Point location & $R_{\mathrm{b}}(\mathrm{m})$ & $Q_{\mathrm{d}}(\mathrm{kg})$ & \multicolumn{2}{c}{$v(\mathrm{~cm} / \mathrm{s})$} & Vibration-isolation ratio (\%) \\
\hline$H_{1}$ & Rear & 100 & 10000 & 9.48 & 6.72 & 29.1 \\
$H_{2}$ & Rear & 200 & 10000 & 5.51 & 4.59 & 16.7 \\
$H_{3}$ & Rear & 300 & 10000 & 3.65 & 3.09 & 15.3 \\
$H_{4}$ & Rear & 400 & 10000 & 2.87 & 2.44 & 15.0 \\
$H_{5}$ & Rear & 500 & 10000 & 1.34 & 1.05 & 21.6 \\
$Y_{1}$ & Side & 200 & 10000 & 5.74 & 4.77 & 16.9 \\
$Y_{2}$ & Side & 250 & 10000 & 4.65 & 3.92 & 15.7 \\
$Y_{3}$ & Side & 350 & 10000 & 1.85 & 1.47 & 20.5 \\
$Y_{4}$ & Side & 450 & 10000 & 1.48 & 1.23 & 16.9 \\
$Y_{5}$ & Side & 550 & 10000 & 1.28 & 0.91 & 28.9 \\
$Y_{6}$ & Side & 850 & 10000 & 1.03 & 0.78 & 24.3 \\
\hline
\end{tabular}

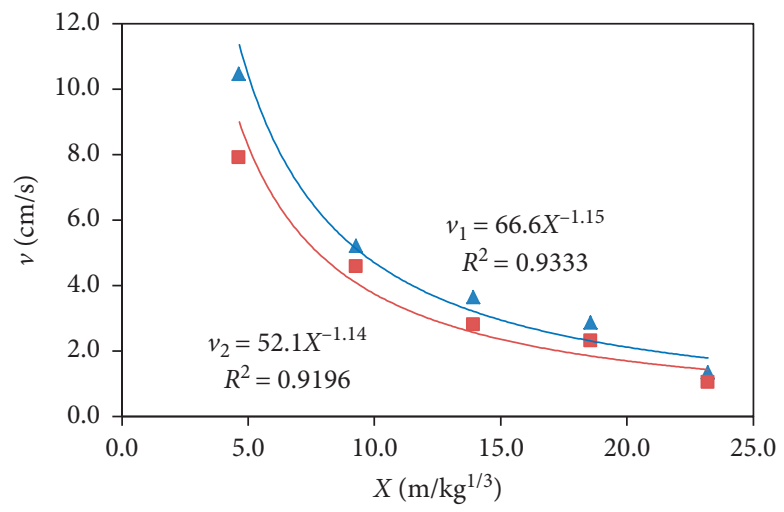

$\triangle S=4.0 \mathrm{~m}$

- $S=3.4 \mathrm{~m}$

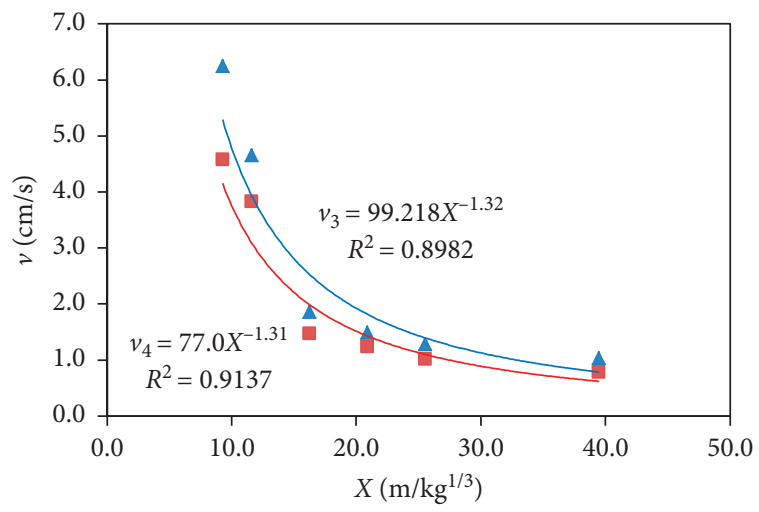

$\Delta S=4.0 \mathrm{~m}$

- $S=3.4 \mathrm{~m}$

(a)

(b)

FIGURE 11: Relationships between vibration velocity of particles and equivalent distance. (a) Monitoring data in the rear and (b) monitoring data to the side.

TABLE 5: Regression analysis results: particle vibration velocity predicted by empirical formula.

\begin{tabular}{lcccc}
\hline$S(\mathrm{~m})$ & \multicolumn{2}{c}{ On the rear } & \multicolumn{2}{c}{ On the side } \\
& $K$ & $\alpha$ & $K$ & $\alpha$ \\
\hline 4.0 & 66.6 & 1.15 & 99.2 & 1.32 \\
3.4 & 52.1 & 1.14 & 77.0 & 1.31 \\
\hline
\end{tabular}

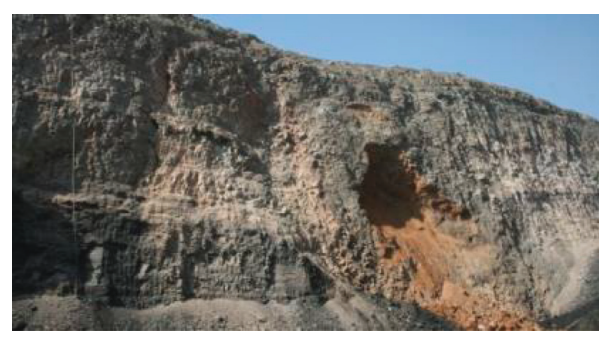

(a)

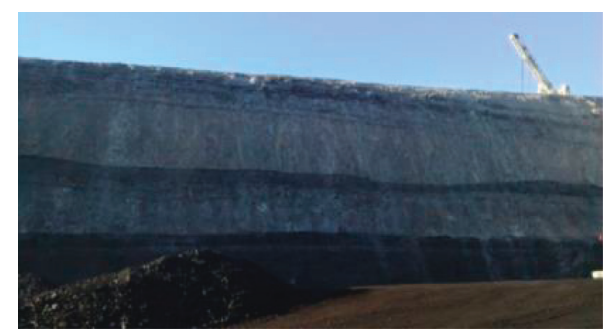

(b)

Figure 12: Presplit blasting effect. (a) Presplit face when $S=4.0 \mathrm{~m}$ and (b) presplit face when $S=3.4 \mathrm{~m}$. 
Regression analysis is conducted on data in Table 4 using formula (15). The results are summarised in Table 5.

$$
v=K\left(\frac{\sqrt[3]{Q_{\mathrm{d}}}}{R_{\mathrm{b}}}\right)^{\alpha},
$$

where $K$ and $\alpha$ denote the attenuation coefficient and the attenuation index.

It can be seen from Table 5 that the attenuation indices for blast-induced vibration change (albeit slightly) while the attenuation coefficients decrease by around $22 \%$ when $S$ is $3.4 \mathrm{~m}$ or $4.0 \mathrm{~m}$. Meanwhile, the in situ testing results revealed that connected cracks were formed under both conditions. The presplit faces were not smooth and suffered the effects of a certain back impact when $S=4.0 \mathrm{~m}$ and spallation was likely to occur (Figure $12(\mathrm{a})$ ); when $S$ is $3.4 \mathrm{~m}$, the presplit face is relatively smooth, with a high half-cast factor (Figure 12(b)). This indicated that the hole spacing calculated using the theoretical formula is greater, and the main reason is that the theoretical formula does not consider the influence of weak structural plane on the strength of rock mass. Therefore, it was finally determined that the hole spacing in presplit blasting in the HDG open-pit coal mines should be $3.4 \mathrm{~m}$, the distance from the presplit blast hole to the cushion hole should be $4.0 \mathrm{~m}$, and the charge mass in each blast hole should be $150 \mathrm{~kg}$. The practical application of the method proved that presplit blasting can reduce the cost of maintenance of slopes, enhancing the stability thereof, and thereby improving the safety of the operation.

\section{Conclusions}

(1) For large-diameter deep holes, an air-deck charge is generally used, and the application of the lowdensity charge is applied to reduce the detonation pressure, increase the charge length, and therefore improve the distribution of stress produced by the explosive in the axial direction of the blast holes. Hole spacing and charge mass are the most important parameters in presplit blasting. If the spacing between blast holes is large, it is difficult to form smooth presplit faces; on the contrary, the number of presplit blast holes needs to be increased, which results in a high drilling cost. A large charge mass in the blast hole is likely to damage the walls of the presplit blast holes, while a low charge mass is unable to form a presplit face.

(2) As the static uniaxial compressive strength $\sigma_{c}$ of rocks increases, the charge mass $Q$ and spacing $S$ of blast holes both grow at a quasiconstant rate with a fixed distance $W$ to the cushion holes. Therein, $Q$ increases at a faster rate. With increasing static uniaxial tensile strength of rocks, the spacing between blast holes and the distance to cushion holes both decrease when using a fixed charge mass in the blast holes, while the rate of decrease gradually slows.
(3) The peak vibration velocity in the axial direction is generally the largest compared with those in vertical and transverse directions. The vector resultant velocity is approximately equal to the axial peak vibration velocity, both appearing quasisimultaneously. The maximum vibration velocity induced by blasting is generally found between 1.2 and $1.8 \mathrm{~s}$. The vibration velocity is initially low, indicating that the blast-induced vibration components contain small-energy $\mathrm{P}$-waves, high-energy S-waves, and surface waves with a low propagation velocity.

(4) When the spacing of presplit blast holes was 3.4 or $4 \mathrm{~m}$ in $\mathrm{HDG}$ open-pit coal mine, the vibration velocity of particles at a hole spacing of $3.4 \mathrm{~m}$ was slower and the average vibration reduction ratio was $20.7 \%$; the attenuation index of blasting-induced vibration changed slightly while the attenuation coefficient decreased by about 22\%; the formed presplit faces were smooth and had a high half-cast factor. Finally, it is determined that the reasonable hole spacing for presplit blasting, distance from presplit blast hole to the cushion hole, and the charge mass in blast holes in the HDG open-pit coal mine are $3.4 \mathrm{~m}, 4 \mathrm{~m}$, and $150 \mathrm{~kg}$, respectively.

\section{Data Availability}

The data used to support the findings of this study are included within the article.

\section{Conflicts of Interest}

The authors declare that there are no conflicts of interest regarding the publication of this paper.

\section{Acknowledgments}

Financial support for this work was provided by the Scientific Research Program funded by Shaanxi Provincial Education Department (Program no. 18JS067) and Innovation Capability Support Program of Shaanxi (Program no. 2018TD-038).

\section{References}

[1] P. K. Singh, M. P. Roy, and R. K. Paswan, "Controlled blasting for long term stability of pit-walls," International Journal of Rock Mechanics and Mining Sciences, vol. 70, no. 9, pp. 388-399, 2014.

[2] B. Mohanty, "Explosion generated fractures in rock and rocklike materials," Engineering Fracture Mechanics, vol. 35, no. 45, pp. 889-898, 1990.

[3] V. K. Singh and D. P. Singh, "Controlled blasting in an openpit mine for improved slope stability," Geotechnical and Geological Engineering, vol. 13, no. 1, pp. 51-57, 1995.

[4] S. K. Mandal, M. M. Singh, and S. Dasgupta, "Theoretical concept to understand plan and design smooth blasting 
pattern," Geotechnical and Geological Engineering, vol. 26, no. 4, pp. 399-416, 2008.

[5] K. Erarslan, Ö. Uysal, E. Arpaz, and M. A. Cebi, "Barrier holes and trench application to reduce blast induced vibration in Seyitomer coal mine," Environmental Geology, vol. 54, no. 5, pp. 1325-1331, 2008.

[6] D. Park, B. Jeon, and S. Jeon, "A numerical study on the screening of blast-induced waves for reducing ground vibration," Rock Mechanics and Rock Engineering, vol. 42, no. 3, pp. 449-473, 2009.

[7] S. A. Tagieddin, "Applicability of blast casting technique in strip-mining phosphate rock," Engineering Geology, vol. 33, no. 2, pp. 127-139, 1992.

[8] M. Sari, E. Ghasemi, and M. Ataei, "Stochastic modeling approach for the evaluation of backbreak due to blasting operations in open pit mines," Rock Mechanics and Rock Engineering, vol. 47, no. 2, pp. 771-783, 2014.

[9] L. Ma, K. M. Li, S. S. Xiao, X. H. Ding, and S. Chinyanta, "Research on effects of blast casting vibration and vibration absorption of presplitting blasting in open cast mine," Shock and Vibration, vol. 2016, Article ID 4091732, 9 pages, 2016.

[10] X. L. Yang and M. S. Wang, "Mechanism of rock crack growth under detonation gas loading," Explosion and Shock Waves, vol. 21, no. 2, pp. 111-116, 2001.

[11] W. M. Ling, "A study on the fracture mechanism of smooth blasting and pre-split blasting," Journal of China University of Mining and Technology, vol. 19, no. 4, pp. 79-87, 1990.

[12] J.-H. Hu, T. Lei, K.-P. Zhou, L. Liu, and D.-Z. Lao, "Mechanism on simulation and experiment of pre-crack seam formation in stope roof," Journal of Central South University, vol. 21, no. 4, pp. 1526-1533, 2014.

[13] F. Cai, Z.-G. Liu, B.-Q. Lin, and W. Li, "Numerical simulation and experiment analysis of improving permeability by deephole presplitting explosion in high gassy and low permeability coal seam," Journal of Coal Science and Engineering (China), vol. 15, no. 2, pp. 175-180, 2009.

[14] F. Cai and Z. G. Liu, "Numerical simulation of improving permeability by deep-hole presplitting explosion in loose-soft and low permeability coal seam," Journal of China Coal Society, vol. 32, no. 5, pp. 499-503, 2007.

[15] F. Wang, S. Tu, Y. Yuan, Y. Feng, F. Chen, and H. Tu, "Deephole pre-split blasting mechanism and its application for controlled roof caving in shallow depth seams," International Journal of Rock Mechanics and Mining Sciences, vol. 64, no. 4, pp. 112-121, 2013.

[16] Q. K. Chen and W. C. Zhu, "Mechanism of the crack formation induced by pre-split blasting and design method for the pre-split blasting hole space," Journal of Northeastern University (Natural Science), vol. 32, no. 7, pp. 1024-1027, 2011.

[17] J. Dai and Y. Q. Yang, "Calculation of the distance between the adjacent delay-explosion shot holes in smooth blasting," Explosion and Shock Waves, vol. 23, no. 3, pp. 253-258, 2003.

[18] K. Cheng and K. G. Zhang, "Inquiry into charge formula for horizontal pre-split blasting," Rock and Soil Mechanics, vol. 22, no. 2, pp. 224-225, 2001.

[19] Z. Aliabadian and M. Sharafisafa, "Numerical modeling of presplitting controlled method in continuum rock masses," Arabian Journal of Geosciences, vol. 7, no. 12, pp. 1-16, 2014.

[20] Z. Liu, Y. Zhang, Z. Huang, Y. Gao, and Y. Zhang, "Numerical simulating research on orifice pre-splitting blasting in coal seam," Procedia Engineering, vol. 45, no. 3, pp. 322-328, 2012.

[21] B. Xie, H. B. Li, C. B. Wang, Y. Q. Liu, X. Xia, and G. W. Ma, "Numerical simulation of presplit blasting influenced by geometrical characteristics of joints," Rock and Soil Mechanics, vol. 32, no. 12, pp. 3812-3821, 2011.

[22] X. D. Qiu, Y. Q. Yu, X. L. Yang et al., "Experiment research of pre-splitting in bedded composite cutting blasting digging," Journal of Chongqing University, vol. 26, no. 7, pp. 108-112, 2003.

[23] M. B. Xu and D. H. Peng, "Parameter optimization of the slope pre-splitting blasting," Explosion and Shock Waves, vol. 28, no. 4, pp. 355-359, 2009.

[24] Ö. Uysal and M. Cavus, "Effect of a pre-split plane on the frequencies of blast induced ground vibrations," Acta Montanistica Slovaca, vol. 18, no. 2, pp. 101-109, 2013.

[25] H. Tang, H. B. Li, Q. C. Zhou, X. Xia, B. Liu, and J. R. Li, "Experimental study of vibration effect of presplit blasting," Chinese Journal of Rock Mechanics and Engineering, vol. 29, no. 11, pp. 2277-2285, 2010.

[26] A. J. Prakash, P. Palroy, and D. D. Misra, "Analysis of blast vibration characteristics across a trench and a pre-split plane," Fragblast, vol. 8, no. 1, pp. 51-60, 2004.

[27] L. R. Myer, "Effects of single fracture on seismic wave propagation," in Rock Joints, N. Barton and O. Stephansson, Eds., pp. 67-473, Bakema, Rotterdam, The Netherlands, 1990.

[28] J. H. Hu, T. Lei, K. P. Zhou, and Q. F. Chen, "Effect of blasting vibration on pre-splitting crack in filling-environment," Journal of Central South University (Science and Technology), vol. 42, no. 6, pp. 1704-1709, 2011.

[29] W. B. Lu, S. X. Lai, and Z. H. Dong, "Analysis of vibration isolating effect of pre-splitting crack in rock excavation by blasting," Explosion and Shock Waves, vol. 17, no. 3, pp. 193-198, 1997.

[30] Y. Hu, W. Lu, M. Chen, P. Yan, and J. Yang, "Comparison of blast-induced damage between presplit and smooth blasting of high rock slope," Rock Mechanics and Rock Engineering, vol. 47, no. 4, pp. 1307-1320, 2014.

[31] J. Dai, "Columnar blasting of rock crushing and fracture circle calculation," Journal of Liaoning Technical University (Natural Science Edition), vol. 20, no. 2, pp. 144-147, 2001.

[32] F. V. Donze, J. Bouchez, and S. A. Magnier, "Modeling fractures in rock blasting," International Journal of Rock Mechanics and Mining Sciences, vol. 34, no. 8, pp. 1153-1163, 1997.

[33] G. W. Ma and X. M. An, "Numerical simulation of blastinginduced rock fractures," International Journal of Rock Mechanics and Mining Sciences, vol. 45, no. 6, pp. 966-975, 2008.

[34] X.-H. An, K.-M. Li, S.-S. Xiao, and W.-M. Hu, "Analysis of key technologies and development of integrated digital processing system for cast blasting design," Journal of Central South University, vol. 22, no. 3, pp. 1037-1044, 2015.

[35] Y. F. Qian, "The mechanism of smooth and pre-cracking blasting," Journal of Chongqing University, vol. 17, no. 1, pp. 126-130, 1994.

[36] Q. Liang, Y. An, L. Zhao, D. Li, and L. Yan, "Comparative study on calculation methods of blasting vibration velocity," Rock Mechanics and Rock Engineering, vol. 44, no. 1, pp. 93-101, 2011.

[37] C. J. Konya, "Presplitting for wall control," Engineering and Mining Journal, vol. 198, no. 5, pp. 45-48, 1997. 


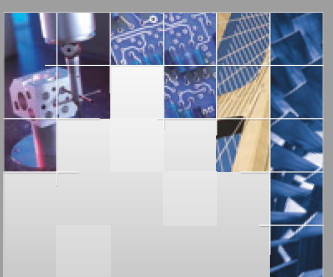

\section{Enfincering}
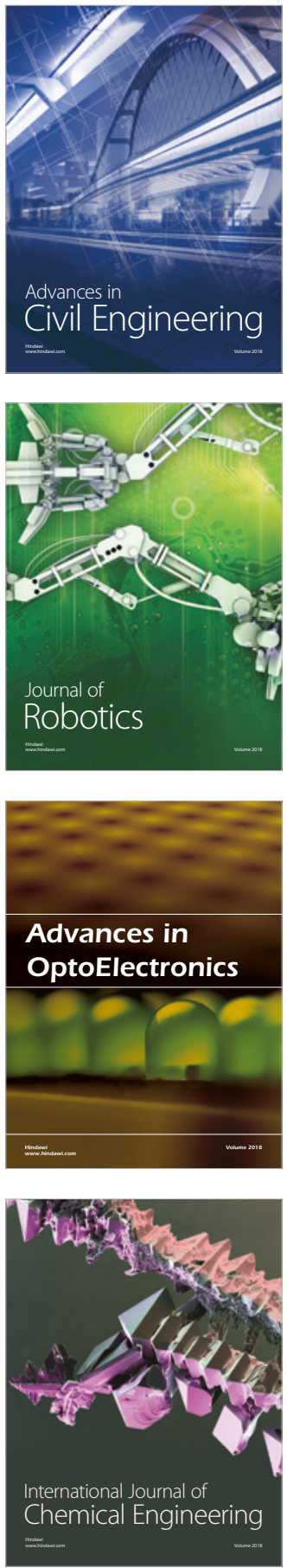

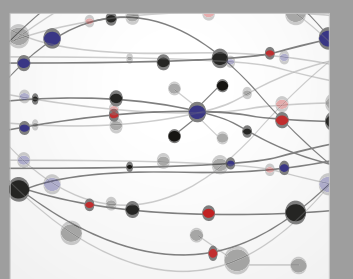

\section{Rotating \\ Machinery}

The Scientific World Journal

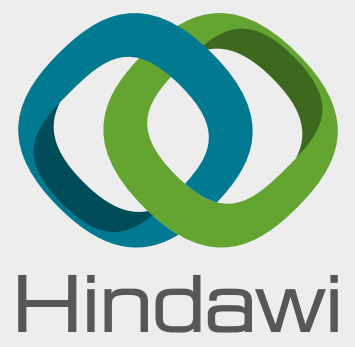

Submit your manuscripts at

www.hindawi.com
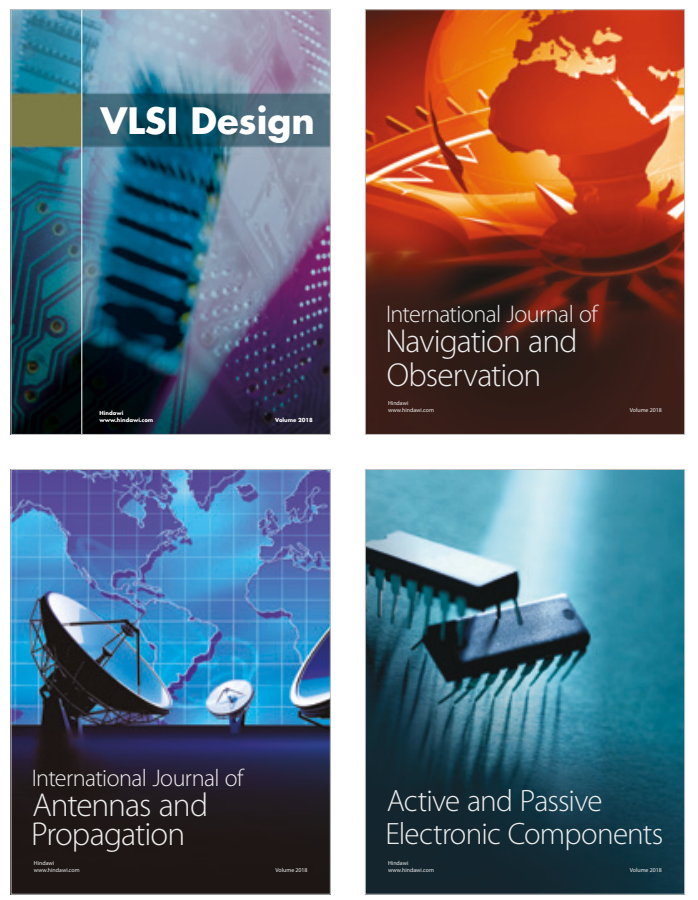
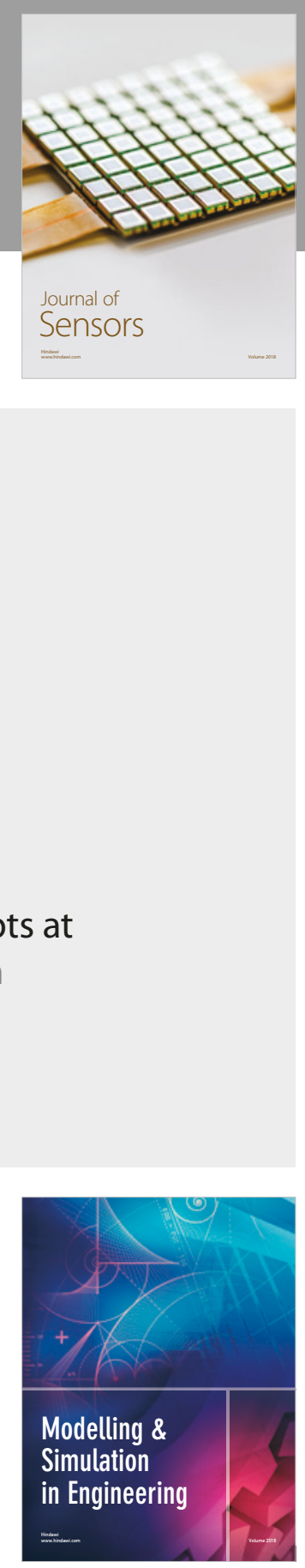

\section{Advances \\ Multimedia}
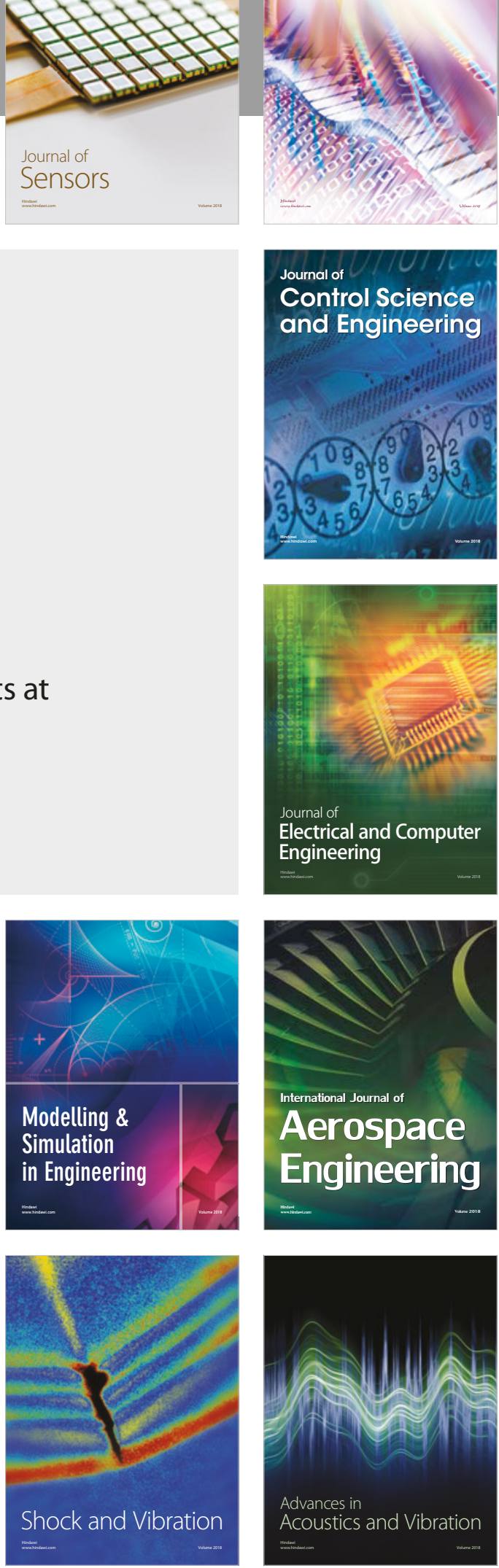